\title{
Green Building in Moscow: Problems and Contradictions
}

\author{
Haris Yakubov ${ }^{1 *}$ \\ ${ }^{1}$ Moscow State University of Civil Engineering, Yaroslavskoe shosse, 26, Moscow, 129337, Russia
}

\begin{abstract}
The article considers issues of green building development as a tool for greening urban spaces. Eco-development is considered not only as an eco-friendly home construction, but also as a maximum possible use of planning, construction and operational resources with the aim of greening urban space. The author examines motivations of the sphere of green building, evaluates relative advantages and disadvantages of introducing green building principles in actual Moscow conditions and provides regulatory materials for eco-development in Russia and abroad.
\end{abstract}

\section{Introduction}

25 years ago, in 1992 at the world ecological congress in Rio de Janeiro for the first time at a high level a thesis on sustainable development was spoken out as the most adequate and modern concept of mankind development strategy. Its essence consists in the fact that real progress is ensured through respecting the balance of interests of society and business in the context to effectively protect environmental conditions and to rationally use natural resources [1].

This concept is extremely important also in relation to urbanized environment where business priorities over public interests, as well as the interests of conservation and protection of natural environment, led to widespread deformation of this environment, to quality deterioration of urban population environmental conditions.

Implementing this theoretically flawless idea (sustainable development), as subsequent years demonstrated, faces obstacles: conflicts of interests in the society, mental unreadiness of the society, financial risks, lack of available technical solutions, etc.

With exclusive clearness, all of this takes place in large cities, metropolitan areas almost everywhere going through a development crisis that is a combination of unmanaged growth with rapid deformation of surrounding environment and quality deterioration of environmental conditions. Starting from the 1960s [2] the voices of experts about the need of humanization become louder, and in recent 10-15 years about greening of urban space [3].

The essence of the concept of humanization and greening is to ensure comfort level of the citizens' life environment by architectural planning, building, organizational and economic measures, to make ecological trend of modern city development most desirable, to organize urban environment in the spirit of eco-friendly city.

*Corresponding author: Yakubov@yandex.ru 
In $70-80$ s of 20 th century across the West, an idea of eco-development became popular as an alternative to traditional, historically developed methods of real estate construction. In the modern sense, eco-development is the construction and modernization of real estate assets using environmental approaches, materials, technologies, with environmental compliance in the design and construction, laying friendly to environment solutions for all life-cycle stages of the assets.

\section{State-of-the-Art}

One of the key evolution factors of eco-development in Russia was the adoption in 2009 of a new law on energy conservation and energy efficiency improvement followed by increased market expectations for further tightening of environmental law enforcement. First state standard (GOST) in the field of eco-development GOST R 54964-2012 "Conformity assessment. Environmental requirements for real estate" came into operation in 2013 [6] updated 01.02.2017). International eco-standards of ISO served as a basis for this standard, however, insufficiently accounting the peculiarities of the Russian market, Russian mentality and the existing state-of-the-art of eco-development. Mechanical transfer of European evaluation criteria does not move the Russian eco-development market closer to foreign (Western) standard, but often makes it much more difficult.

Green building is not yet a strong tendency in Russia, considering its relatively short history compared with nearly 25 years of experience in eco-development in the United States and Western Europe. In Russia, its own system of eco-development facilities certification is so far absent, for this reason provisions of international systems LEED, BREEAM are regarded as evaluation criteria. However, in the field of residential construction these requirements are hard-to-reach, they are unadjusted to real Russian conditions, which on the first hand, holds down the volumes of such construction, and on the second hand, lays the background for attempts to avoid these requirements. Although, certainly, international certificates are needed as a guide, as a sort of optimum level that should be aspired. Implementing the principles of eco-development in Western countries is enabled mainly by ethical considerations and the system of priorities established in the given techno-economic paradigm in lifestyle and values modelling, but in Russia, it is mainly a demand. Moreover, this demand is produced by two components that are financial possibilities and motivations defined by environmental priorities, i.e. ecological consciousness. In addition, unfavorable environmental situation in Moscow suggests also heavy expenses on construction of ecohomes.

From this perspective, quite demonstrative example is Moscow. First place in preferences ranking in Moscow is firmly hold by central districts, and primarily by Ostozhenka Street, so-called "golden mile", which is included according to British edition of Wealth-Bulletin in the top ten of the most expensive streets in the world [7]. New Arbat Avenue, Yakimanka and Tverskaya Streets are also considered prestigious. All of these addresses are characterized by densely build-up areas, intensive vehicular traffic, high level of air pollution by exhaust fumes and by the absence in close vicinity of any significant, from an environmental point of view, landscaped areas. Environmental situation in these districts is characterized as extremely unfavorable. As a result, even for the most wealthy people for which increase of real estate cost for $8-10 \%$ (eco-house is exactly by as much expensive at the average according to many sources does not appear to be burdensome, environmental priorities are not decisive.

Publications often make references to the fact that low demand for eco-development in part of energy efficiency is explained in Russia by low prices on energy carriers [8]. However, firstly, even existing rates (low as compared to European) for the majority of population are considerable, and secondly, real climatic parameters, that are cold winters, 
short daylight hours in wintertime, construction of foundation under frost susceptible soil conditions, etc. reduce these differences in rates. Furthermore, a need arises for energyconsuming enhanced air conditioning in the house located in environmentally unfriendly district, which contradicts to one of the principles of green building, i.e. reduction in expenses for maintaining real estate assets. Another fundamental principle of ecodevelopment is the use of eco-friendly construction materials, eliminating the possibility of negative influence on human health. Studies of environmental hygienists show [9] that after abolition in 2010 obligatory hygienic certification of constructive and finishing materials the urgency of construction materials security issues has increased many times due to intensive introduction of polymeric construction and finishing materials, insufficiently studied construction materials, widespread use of synthetic detergents, cleaners and cosmetic products, etc.

The degree of environmental risk associated with the use of such materials is testified by data on the content in construction and finishing materials (mastics, sealants, plasticizing agents for concrete, linoleum, thermal insulating materials, varnishes, paints, cement and concrete with the addition of waste products, etc.) of toxic and high-toxic substances: formaldehyde, phenol, styrene, benzol, xylol, chrome, etc. It is clear that eco-development using such materials is out of the question. Implementation of abolished or even more perfect quality control system of construction materials, start of production of eco-friendly materials instead of used today - all this is connected with large financial expenses that shall affect respectively the value of environmental real property units.

One of generally accepted instruments to provide energy efficiency and to upgrade the building comfort level is proper organization of premises insolation. Increasing the area of glassed spaces in the conditions of Moscow (short daylight hours during the winter, early spring and late fall is somewhere about 5 months) shall not ensure desired economic effect. In addition, overbuilt site development on a large area of the city, infill development, violation of buildings' accommodation often does not provide even the minimum required level of natural illumination of residential accommodation.

Essential comfort condition of living environment indoor is to observe noise standards, in other words to ensure effective sound insulation. As regards to building codes, the value of airborne noise insulation is sufficient if the thickness of reinforced concrete floor is not less than $160 \mathrm{~mm}$. However, even if the thickness of the floor is $200-250 \mathrm{~mm}$ (precisely such floor is now used in the construction of most frame-monolithic residential houses) standardized noise value is not assured and requires the use of additional soundproofing devices. Very often property developers do not perform these works.

The primary source of noise in Moscow (as well as primary source of air pollution) is transport. Protection from traffic noise can provide covering the facade of the building with soundproofing material and installation of multi-chamber insulating glass units that is a quite costly work, which shall certainly affect real property value.

Effective noise protection remedy of residential development is the so-called "tree lawns" between a highway and residential houses. Properly arranged these strips can reduce noise levels by $30 \%$. However, in recent years, it is rarely used in Moscow and in connection to enlargement of highways, even existing tree lawns are cut down. Although the mere fact of giant scale of highway construction in Moscow, turning urban streets into high-speed lines, etc. contradicts to modern trends of solving transportation problems in the city [10].

Widely distributed in recent years, the concept of "green" building as a word-for-word translation of the English "green building" coincides in sounding with traditional Russian term "green building" which means gardening.

However, if under "green building" we understand not only construction of eco-homes, but also the entire context of greening the urban space, then the role of green planting as an environmental and economic resource for forming healthy environment is hard to overestimate [11].//// 
Green planting in the city has a tremendous environmental potential. The degree of landscaping is an important indicator not only of environmental well-being of the city, but also of its investment attractiveness. Nevertheless, this dependence is not always straightforward sometimes it is contradictory as is the case in Moscow.

Moscow is one of the most landscaped big cities of the world. Almost half of the city area is covered with plants: hundreds of boulevards and public gardens, dozens of parks. Moscow is the only metropolis the territory of which accommodates a unique National Park "Elk Island", etc. Each year tens and hundreds of thousands trees and shrubs are planted in the city. And at the same time, according to data of the Federal State Statistics Service for 2014 Moscow is one of the most environmentally troubled cities in Russia conceding in terms of pollutant emissions volume only to Norilsk [12]. Analyzing the origins of this contradiction is beyond the scope of this article and the author examined it in special publications [13].

\section{Results}

Despite the popularity of the idea of humanizing urban space, real accomplishments of ecodevelopment in Russia remain more than modest. Against the background of total construction volumes in the country, 43 certified facilities (as of 2016) are unnoticeable at all, however only $2 \%$ of them accounts for residential real estate [4]. In Moscow, certified real estate units are represented only by office buildings. As the result, today it is needless to talk about any significant role of eco-development in greening urban space having in mind an eco-house as a comprehensive, completed object.

There are quite a number of reasons of Russia's lag from the level of Western countries in this area, including: conflicts of interests in the society, mental unreadiness of the society, financial risks, deficiency of available technical solutions, etc. In general terms, this lag could be explained by differences in techno-economic paradigm as per Glazyev S.Yu. [5].

It is possible to name some "green" technologies, which have well proved in Europe, in particular during the construction of "Green twins" (Deuche Bank) in Germany:

- Recycling. Processing and reuse of $98 \%$ of the waste which has remained from reconstruction of the old building.

- The improved thermal insulation. New two-chamber windows and the improved isolation don't allow overheating in the summer and reduce thermal losses in the winter more than by $60 \%$.

- Motion sensors. Thanks to automated management lighting joins, only when it is necessary and where it is necessary.

- Energy efficient lamps.

- Natural light. Optimization of use of an available daylight considerably reduces energy consumption.

- Power active elevators. Depending on the direction of the movement and loading elevators also generate electricity which moves back in power network.

- Energy saving office equipment. In general the need for electricity of buildings is reduced by $55 \%$.

- Water recycling. Rain water and household sewage are reused after cleaning in the systems of external watering and also for washout in toilets and urinals that provides decrease in water consumption more than for $40 \%$.

- Alternative power engineering. More than 50\% of hot water, necessary for domestic needs, heat up solar collectors. Surplus of heated water is redirected to the system of heating.

\section{Discussion}


Thus, despite attractiveness of green building ideas, obvious advantages as compared with traditional construction (energy efficiency, comfort of life environment and absence of negative impact on the environment) realizing these ideas in real-life conditions of Russian metropolis is related to a number of objective difficulties.

According to the experts, there are some reasons which precent the development of "green" construction in Moscow.

Firstly, there is a mentality of the people who have not got used to be engaged in ecological building yet. Besides, in Russia there are a lot of Construction Rules and Regulations, which have become outdated, work still. According to them them, Gosekspertiza's representatives still can try to find out why this or that technology which leads to the rise in price of construction is used. Besides, there are no narrow experts. For example, power modeling is necessary for green construction, but such experts, able to do power models, are not enough in the country and in Moscow in particular.

We often speak about high cost of green construction. There is an opinion, that so far our economy is not rich, so green construction is an inaccessible luxury. But not all the experts agree with this opinion.

Of course, the construction branch in Russia has the specifics and there are many unclear features. So, in the country where the labour and construction materials cost very little, the final product is too expensive. At the same time there are a few construction companies, which build whole settlements with the use of ecological technologies. At the same time, their housing are supposed for the economy class. So that, green construction is not obligatory an expensive construction.

\section{Conclusion}

From our point of view, the main reasons for little real transforming ideas of ecodevelopment into action in Moscow and in Russia in general, are:

1. Deficiencies in the legal framework - lack of clear Russian standards and defined certification criteria, taking into account the specificity of Russian market

2. Unavailability for a wide range of technological applications and insufficient quality control of building materials used in construction

3. Lack of principles of strategic planning in the sphere of urban environment

4. Mentality of the major part of the population, which involves insufficient public demand for building innovations.

\section{References}

1. Report of the United Nations Conference on Environment and Development. (Rio de Janeiro, 3-14 June 1992) (Access Mode 20.05.2018) http://www.liveinternet.ru/users/3084963/post220452571/

2. J. Jacobs, The Death and Life of Great American Cities (Moscow, New Publishing House, 2011)

3. J. Gehl, Cities for People (Moscow: Concern "Krost": Alpina Publisher, 2012)

4. O. Kondrachuk, Y. Petrenko, Fundamental Research, 11-3, 579-583 (2015)

5. S. Glazyev, Economics of Contemporary Russia, 2 (57), 27-42, (2012)

6. A. Bolotin, V. Bakayev, Journal of Human Sport and Exercise 12, 405-413 (2017) pp., doi:10.14198/jhse.2017.122.17

7. A. Vasilieva, Bulletin of the Institute of Economics and Management of the Yaroslavthe-Wise Novgorod State University, 2, 7-12 (2015) 
8. Yu. Gubernskiy, For Building Materials to be Safe, San-EpidemControl, 6, 43-47 (2012)

9. V. Vuchic, Transportation for Livable Cities. Territory of the future (Moscow, 2011)

10. H. Yakubov, Ecology of Urbanized Territories, 3, 66-69

11. E. Chibisova, Economy and Entrepreneurship, 5-2 (58-2), 600-603 (2015)

12. H. Yakubov, Problems of landscaping large cities", XVII, 146-150

13. A. Bolotin, V. Bakayev, Journal of Physical Education and Sport 16, 1177-1185 (2016), doi:10.7752/jpes.2016.04188 